\title{
Asymmetric synthesis of tertiary thiols and thioethers
}

Jonathan Clayden* and Paul MacLellan

\author{
Review \\ Address: \\ School of Chemistry, University of Manchester, Oxford Rd, \\ Manchester M13 9PL, UK \\ Email: \\ Jonathan Clayden* - clayden@man.ac.uk \\ * Corresponding author \\ Keywords: \\ asymmetric synthesis; organolithium; sulfur; substitution; thiol
}

\author{
Beilstein J. Org. Chem. 2011, 7, 582-595. \\ doi:10.3762/bjoc.7.68 \\ Received: 02 February 2011 \\ Accepted: 15 April 2011 \\ Published: 10 May 2011 \\ Associate Editor: I. Marek \\ (C) 2011 Clayden and MacLellan; licensee Beilstein-Institut. \\ License and terms: see end of document.
}

\begin{abstract}
Enantiomerically pure tertiary thiols provide a major synthetic challenge, and despite the importance of chiral sulfur-containing compounds in biological and medicinal chemistry, surprisingly few effective methods are suitable for the asymmetric synthesis of tertiary thiols. This review details the most practical of the methods available.
\end{abstract}

\section{Introduction}

Organosulfur compounds play key roles in many biological structures and functions: two of the 21 proteinogenic amino acids contain sulfur, and seven of the 10 best-selling drugs in the US in 2009 were organosulfur compounds (Figure 1) [1]. Glutathione plays a crucial role in primary metabolism, and $(R)$ thioterpineol (limonenethiol or "grapefruit mercaptan") is an important and extremely powerful flavour compound, providing the distinctive taste of grapefruit (Figure 2). The consequent need to prepare and manipulate enantiomerically pure organosulfur species has powered the development of asymmetric synthetic methods leading to various classes of organic sulfur compounds, with chirality residing at sulfur, at carbon, or at both [2-8].

This field of asymmetric organosulfur chemistry is particularly well developed in connection with sulfur(IV) and sulfur(VI) species with chirality at sulfur - namely sulfoxides, sulfinates, sulfimines and sulfilimines [9]. Chiral sulfoxides and sulfonium ylids have themselves been extensively used as tools for asymmetric synthesis [3]. With regard to chiral sulfur(II) compounds - namely thiols and thioethers (sulfides) with chirality at carbon - methods available for their asymmetric preparation are abundant, and usually rely on stereospecific substitution reactions [9]. These reactions are well suited to the construction of secondary thiol derivatives. By contrast, few methods are suitable for the asymmetric preparation of simple tertiary thiols $\mathbf{1}$. While the asymmetric synthesis of simple tertiary alcohols is generally achieved by controlling enantiofacial selectivity in nucleophilic attack on a prochiral ketone [10], comparable approaches to tertiary thiols $\mathbf{1}$ are not practical due to the instability of thioketones, their tendency to undergo nucleophilic attack at sulfur rather than carbon, and their intol- 
<smiles>COc1ccc2nc(S(=O)Cc3ncc(C)c(OC)c3C)[nH]c2c1</smiles>

Nexium $\$ 5.01$ billion

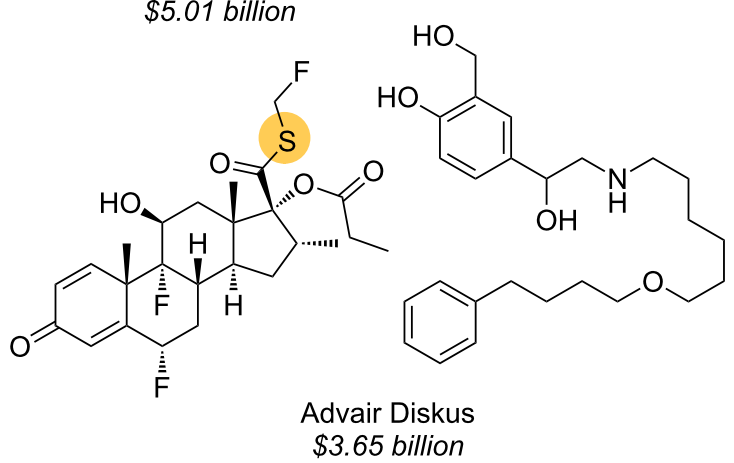

$\$ 3.65$ billion<smiles>CC(C)(O)c1ccccc1CC[C@H](SCC1(CC(=O)O)CC1)c1cccc(/C=C/c2ccc3ccc(Cl)cc3n2)c1</smiles>

Singulair $\$ 3.03$ billion

Plavix $\$ 4.22$ billion<smiles>COC(=O)C(c1ccccc1Cl)N1CCc2sccc2C1</smiles><smiles>OCCOCCN1CCN(C2=Nc3ccccc3Sc3ccccc32)CC1</smiles>

Seroquel $\$ 3.12$ billion<smiles>CCc1ccc(CCOc2ccc(CC3SC(=O)NC3=O)cc2)nc1</smiles><smiles>Cc1c(OCC(F)(F)F)ccnc1CS(=O)c1nc2ccccc2[nH]1</smiles>

Figure 1: Seven out of the ten top selling drugs in the USA in 2009 contain sulfur. Figures in italics are total retail sales in dollars [1].<smiles>N[C@@H](CCC(=O)N[C@@H](CS)C(=O)NCC(=O)O)C(=O)O</smiles><smiles>CC1=CCC(C(C)(C)S)CC1</smiles>

$(R)$-thioterpineol

Figure 2: Naturally occurring organosulfur compounds glutathione and $(R)$-thioterpineol.

erable stench [11]. As a result, enantiomerically pure tertiary thiols are a remarkably difficult class of compounds to make, despite the simplicity of their structure. This review will cover the methods available for the asymmetric synthesis of chiral tertiary thiols and their sulfur(II) derivatives.

Two general approaches to the preparation of a chiral tertiary thiol 1 may be envisaged, entailing disconnection of either a $\mathrm{C}-\mathrm{S}$ or a $\mathrm{C}-\mathrm{C}$ bond (Figure 3 ). The thiol could be installed by stereoselective attack of a sulfur-centred nucleophile on a substituted carbon centre (C-S bond formation). Alternatively, stereoselective alkylation, arylation or acylation of a secondary sulfur-based substrate could generate the quaternary centre (C-C bond formation).

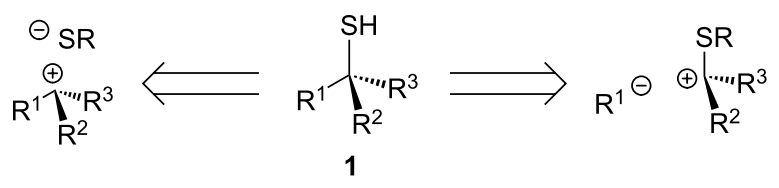

Figure 3: Methods for the synthesis of chiral tertiary thiol 1.

\section{Review}

\section{Carbon-sulfur bond formation}

\section{$1.1 \mathrm{~S}_{\mathrm{N}} 2$ displacement of a leaving group}

Stereospecific nucleophilic attack on substituted carbon atoms is a simple and versatile way to construct stereocentres next to heteroatoms with overall inversion of stereochemistry. Sulfur nucleophiles are commonly used very effectively to accomplish reactions of this type [9]. However, $\mathrm{S}_{\mathrm{N}} 2$ displacements are very sensitive to steric crowding at the reaction centre: $\mathrm{S}_{\mathrm{N}} 1$ substitu- 
tion and elimination reactions are almost always favoured over the $\mathrm{S}_{\mathrm{N}} 2$ pathway in quaternary electrophiles, limiting the use of $\mathrm{S}_{\mathrm{N}} 2$ reactions for the synthesis of tertiary thiols.

\subsubsection{Sulfonate leaving groups}

The efficiency of sulfonates as leaving groups has allowed the preparation of certain families of tertiary thiols and thioethers. For example, $\mathrm{S}_{\mathrm{N}} 2$ displacement of a mesylate leaving group by thiophenol can be accomplished using $\alpha$-hydroxy esters 2 (Scheme 1) [12].

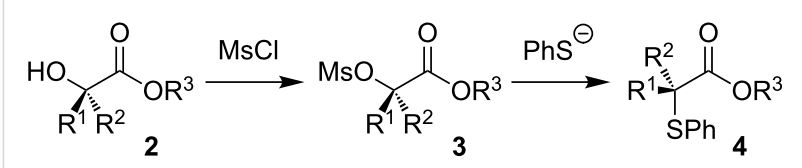

Scheme 1: Preparation of thioethers 4 from a-hydroxy esters.

The presence of the $\alpha$-ester group of $\mathbf{3}$ promotes $\mathrm{S}_{\mathrm{N}} 2$ reaction in two ways: The electron-withdrawing nature of the substituent inhibits $\mathrm{S}_{\mathrm{N}} 1$ dissociation and carbocation formation, and the planar ester group poses minimal steric hindrance towards approach of the nucleophile.

Yields of substitution in $\alpha$-aryl- $\alpha$-hydroxy esters 5 are poor with a significantly decreased enantiomeric ratio in the product 6 (Scheme 2). The low yields can be attributed to the formation of $\beta$-phenylthioesters 7 by elimination followed by conjugate addition. Even in the presence of the adjacent carbonyl group, competing $\mathrm{S}_{\mathrm{N}} 1$ dissociation of the benzylic leaving group leads to a loss of enantiomeric purity in some cases. The use of $\alpha, \alpha-$ dialkyl hydroxy esters $\mathbf{8}$ is more successful: Thioethers $\mathbf{1 0}$ are formed in high yield and with almost complete stereospecificity (Scheme 3).

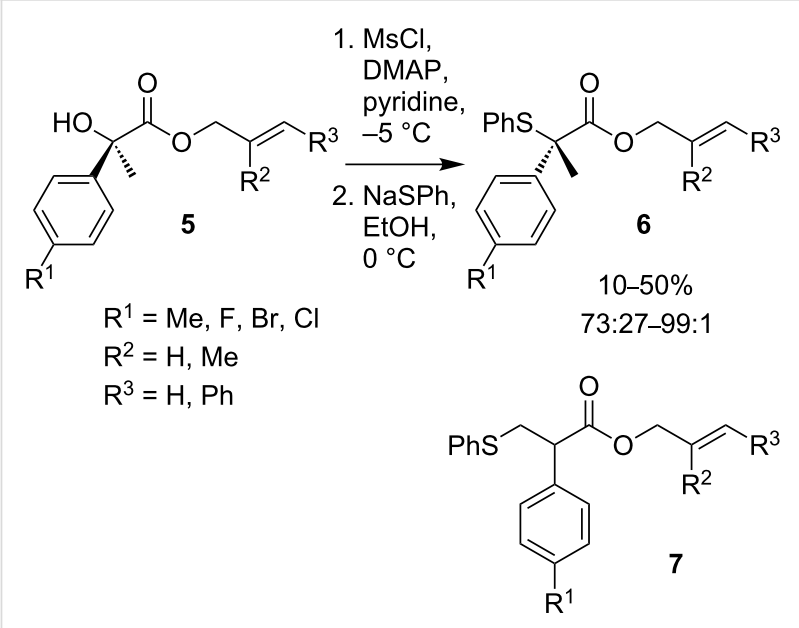

Scheme 2: Nucleophilic substitution in a-aryl-a-hydroxy esters.

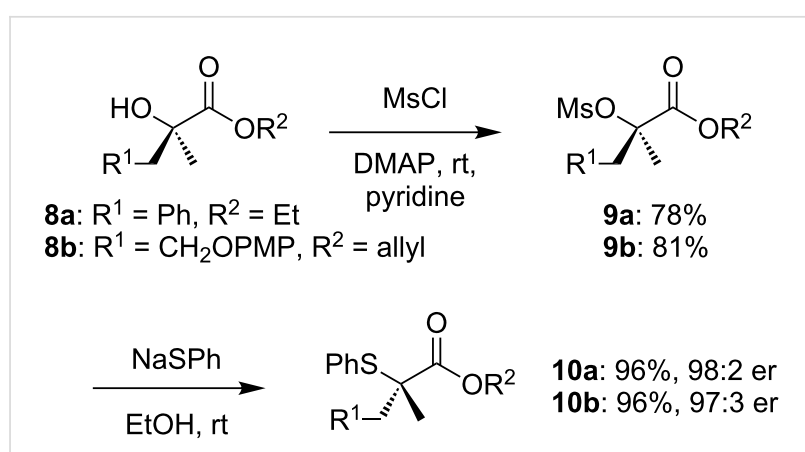

Scheme 3: Preparation of $\alpha, \alpha$-dialkylthioethers.

Using the same principles of low steric bulk and electronic inhibition of the $S_{N} 1$ reaction pathway, $\alpha$-(sulfonyloxy)nitriles, easily prepared from cyanohydrins, can also be made to undergo $\mathrm{S}_{\mathrm{N}} 2$ reaction with sulfur nucleophiles [13]. However, substitution of the quaternary $\alpha$-(sulfonyloxy)nitrile $\mathbf{1 1}$ is very slow, and conversion of $\mathbf{1 1}$ to $\mathbf{1 2}$ with potassium thioacetate in DMF proceeds in only $35 \%$ yield after 72 hours. $\mathrm{S}_{\mathrm{N}} 2$ displacement of the leaving group by thioacetate in toluene proceeds faster at $55^{\circ} \mathrm{C}$ (Scheme 4).<smiles>CCCCC(C)(C#N)OC</smiles>

11

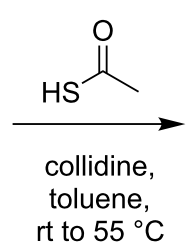

$14 \mathrm{~h}$

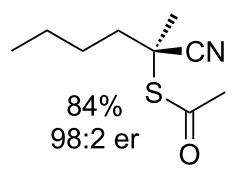

12
Scheme 4: Preparation of a-cyanothioacetate 12.

The synthesis of the unnatural enantiomer of the natural product spirobrassinin has been achieved by substitution at a quaternary centre by a sulfur nucleophile [14]. Intramolecular cyclisation of a dithiocarbamate $\mathbf{1 3}$ allows isolation of $\mathbf{1 4}$ with complete inversion of stereochemistry, although no yield for this reaction was reported (Scheme 5).<smiles>CSC(=S)NC[C@]1(O)C(=O)Nc2ccccc2[C@]1(O)[Mg][Mg]</smiles>

$(R)-(+)$-spirobrassinin

Scheme 5: Synthesis of $(R)-(+)$-spirobrassinin. 
Peregrina and co-workers have developed a general method for the synthesis of $\alpha$-functionalised $\beta$-amino acids [15-17] employing nucleophilic ring opening of cyclic sulfamidate 15 via an invertive $S_{N} 2$ mechanism (Scheme 6) [16].

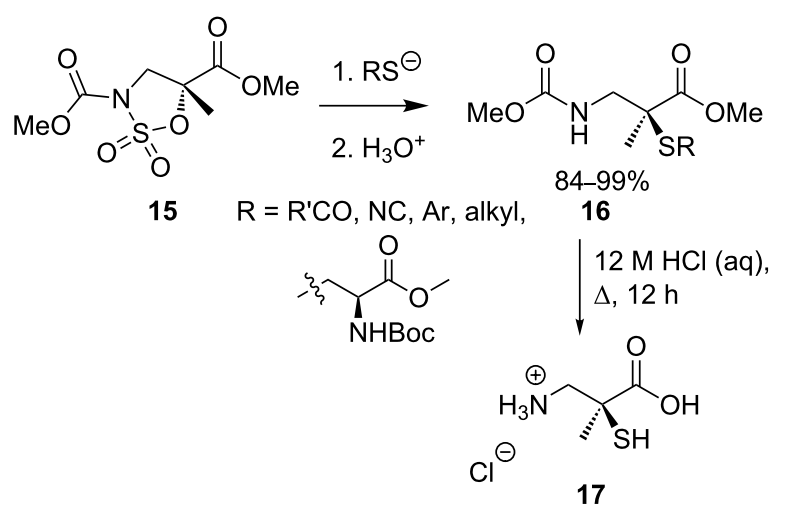

$\mathrm{R}=\mathrm{Ac}: 63 \% ; t-\mathrm{Bu}: 71 \%$

$\mathrm{Ph}_{3} \mathrm{C}: 88 \%$; PMB: $91 \%$

Scheme 6: Opening of cyclic sulfamidates with thiol nucleophiles.

A variety of nucleophiles are capable of ring opening the sulfamidate $\mathbf{1 5}$ in good yields, and simple functional group transformations allow isolation of the functionalised $\beta$-amino acids. Sulfur-based nucleophiles generally undergo reaction with sulfamidate $\mathbf{1 5}$ cleanly to give products $\mathbf{1 6}$ with complete inversion of configuration [16,17]. Acid catalysed cleavage of a thioether or thioacetate yields tert-thiols $\mathbf{1 7}$ in good yield.

\subsubsection{Epoxide ring opening}

$\mathrm{S}_{\mathrm{N}} 2$ displacements from quaternary electrophiles require specific structural features to avoid competing racemisation: Excellent leaving groups and electron withdrawing, nonaromatic and small substituents at the reactive centre all favour invertive substitution. Under basic conditions, epoxides also undergo invertive reactions, even at quaternary centres. Sulfurbased nucleophiles have been employed in nucleophilic ring opening of epoxides in hindered systems [18-23], with most examples of the latter occurring at quaternary carbon atoms which are part of ring systems [18-22], and in particular in steroids [18-20]. For example, the thiol-containing androgen 19 is prepared in $71 \%$ yield by epoxide ring opening of $\mathbf{1 8}$ with potassium hydrogen sulfide (Scheme 7) [18].

Epoxide ring opening by a sulfur nucleophile was also employed as the key step in the synthesis of (+)-BE-52440A (22) [22] (Scheme 8). Dimerisation of nanaomycin derivative 21 through a bridging sulfide involves a double regioselective invertive epoxide opening.

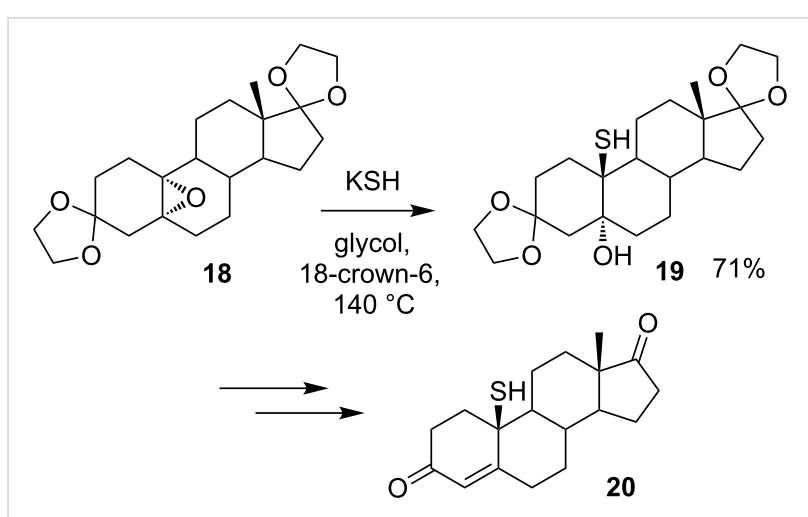

Scheme 7: Synthesis of androgen 20.

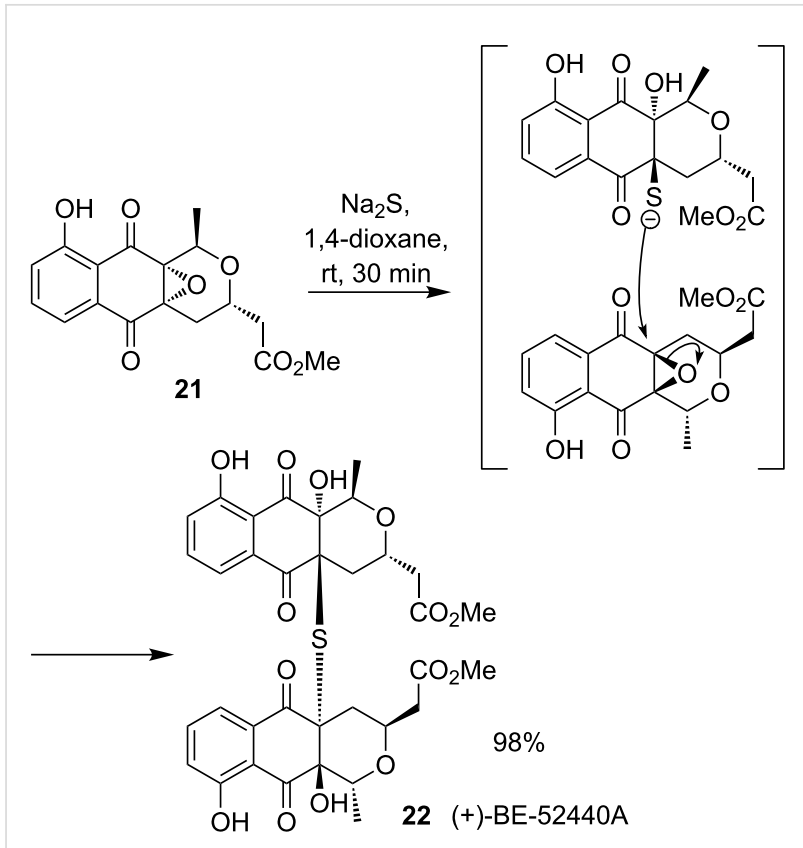

Scheme 8: Synthesis of (+)-BE-52440A.

\subsubsection{Mitsunobu reactions}

The Mitsunobu reaction offers an operationally straightforward method for activating simple alcohols to invertive substitution, and it is widely used for constructing new stereodefined carbon-heteroatom bonds [24,25]. The Mitsunobu reaction proceeds by reaction of a phosphine and DIAD or DEAD with an alcohol 23 to form an $O$-phosphinite leaving group (Scheme 9). $\mathrm{S}_{\mathrm{N}} 2$ substitution to yield $\mathbf{2 4}$ is accompanied by formation of a phosphine oxide.

There are many examples of the use of sulfur nucleophiles in the Mitsunobu reaction [25-27]: The reaction is successful with a wide range of primary and secondary alcohols, but Mitsunobu-type reactions are very sensitive to steric bulk at the electrophilic carbon atom. For example, reaction of alcohol 25 


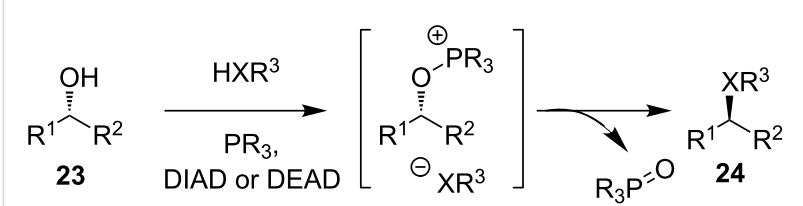

Scheme 9: The Mitsunobu reaction.

with a phenol under standard Mitsunobu conditions at $50{ }^{\circ} \mathrm{C}$ for 16 hours provides only a trace amount of the desired chiral ether $\mathbf{2 6}$, while reaction at $100{ }^{\circ} \mathrm{C}$ allows isolation of $\mathbf{2 6}$ in moderate yield (Scheme 10) [28]. A gem-diethyl analogue of 25 failed to give any substitution at all, the major product being the result of elimination.

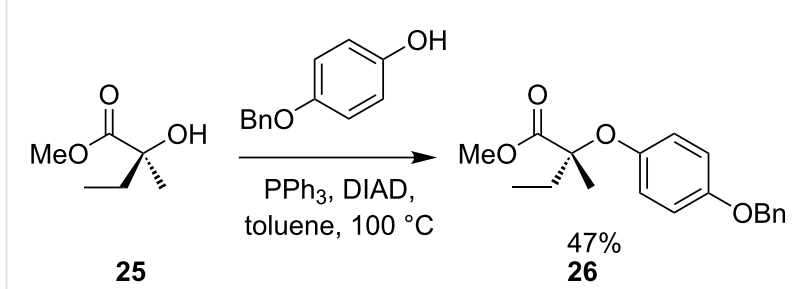

Scheme 10: Mitsunobu substitution at a quaternary centre.

Despite the proven reluctance of tertiary alcohols to undergo Mitsunobu reactions, there is one example of the displacement of a tertiary alcohol by a thiol under Mitsunobu conditions in the literature. La Clair reported the synthesis of the initially assigned structure of natural product hexacyclinol (27, Figure 4) [29].

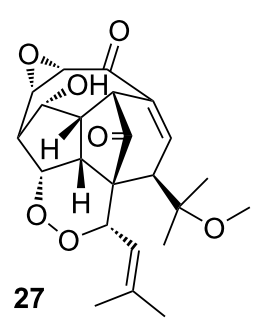

Figure 4: Initially assigned structure of hexacyclinol.

The reported synthesis entailed Mitsunobu reaction at a very hindered quaternary centre, accomplishing invertive substitution of $\mathbf{2 8}$ with thiophenol under mild reaction conditions to yield 29 in 94\% yield (Scheme 11).

The paucity of literature precedents for Mitsunobu reactions of tertiary alcohols brings into sharp focus the remarkable success of this reaction under such mild conditions. However, this reac-

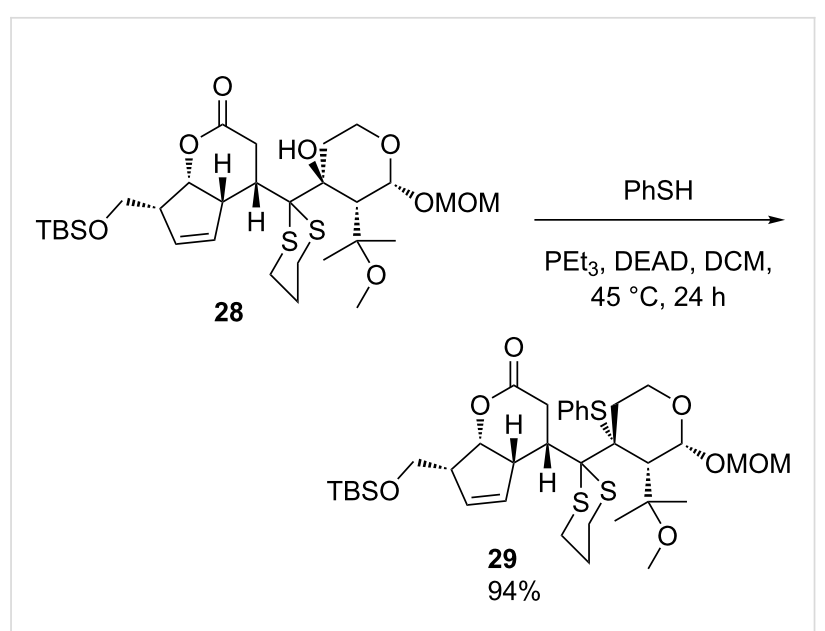

Scheme 11: Preparation of thioether 29.

tion and other unusual steps in the synthesis attracted scepticism among synthetic chemists [30], and many aspects of this synthesis were called into question when a revised structure of hexacyclinol was proposed by Rychnovsky [31]. A successful synthesis of the revised structure matched the published data for the natural compound [32].

A modification of the Mitsunobu reaction, that does allow the formation of sulfur-substituted tertiary carbon atoms with inversion of stereochemistry, was reported by Mukaiyama and co-workers $[33,34]$. The method employs benzoquinone derivatives instead of azodicarboxylates as the oxidising agent. A series of phosphinites $\mathbf{3 1}$ was prepared by treatment of alcohols 30 with chlorodiphenylphosphine in the presence of triethylamine and DMAP. $\mathrm{S}_{\mathrm{N}} 2$ substitution of the phosphinites proceeds by oxidative activation of the leaving group with a 1,4-benzoquinone derivative, DBBQ (35) being most effective (Scheme 12). Addition of a thiol nucleophile to adduct 32 results in $\mathrm{S}_{\mathrm{N}} 2$ inversion and isolation of the enantiomerically pure (94:6-99:1 er) tertiary thioether $\mathbf{3 3}$ and by-product $\mathbf{3 4}$. Highest yields were obtained with BtzSH (36) and BoxSH (37).

The reaction proceeds well with many hindered substrates incorporating aromatic, alkyl and ester substituents with excellent stereospecificity. Enantiomerically pure thiols can also be made from the product: Aromatic thioether $\mathbf{3 8}$ is reduced with lithium aluminium hydride to give 39 in $95 \%$ yield (Scheme 13).

The methodology was later refined to allow substitution of alcohols in 1 step. Phenoxydiphenylphosphine was used to prepare the phosphinite intermediate and an azide was used as the oxidising agent instead of a benzoquinone derivative (Scheme 14) [35-37]. 


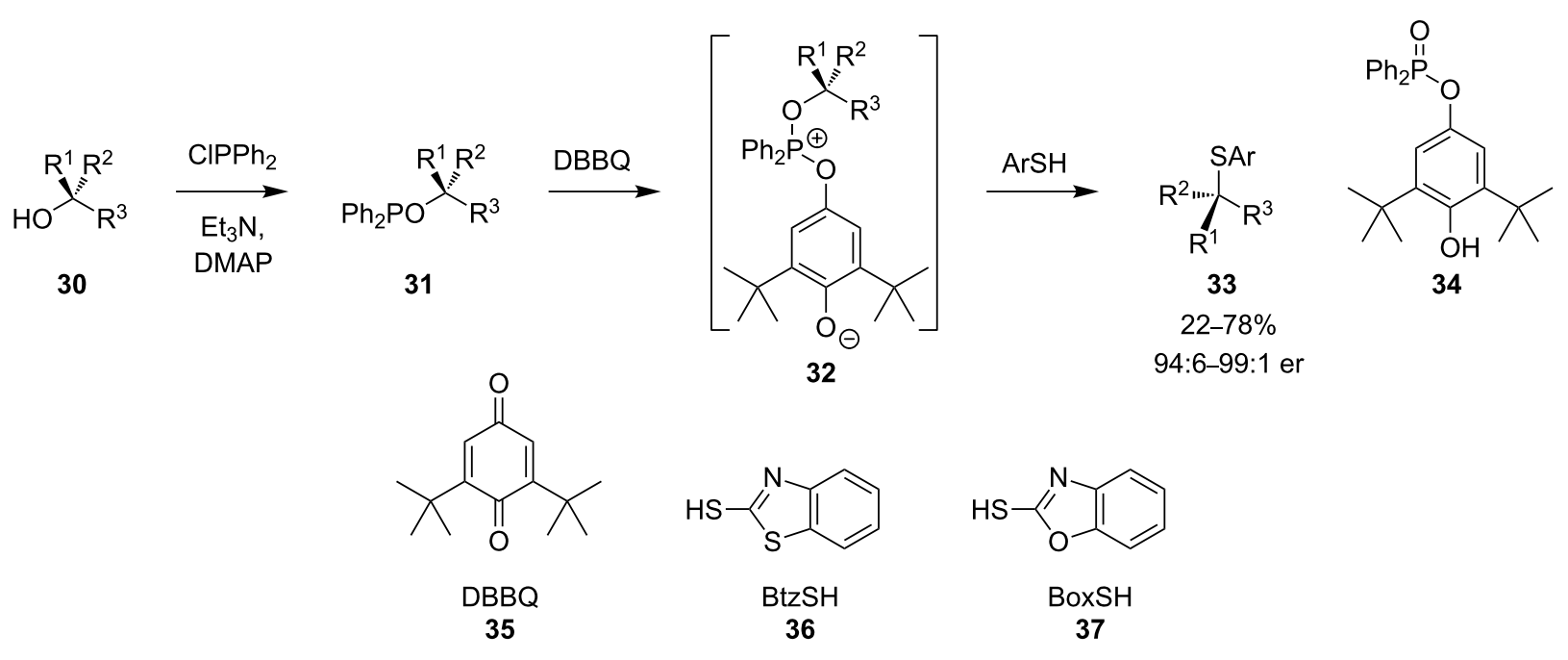

Scheme 12: Thioethers 33 prepared from phosphinites 31 .<smiles>COC(=O)[C@](C)(Sc1nc2ccccc2s1)c1ccccc1</smiles>

38

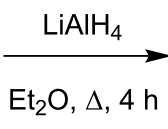

$\mathrm{Et}_{2} \mathrm{O}, \Delta, 4 \mathrm{~h}$<smiles>CC(S)(CO)c1ccccc1</smiles>

39

$95 \%$
Scheme 13: Preparation of enantiomerically pure thiol 39.

These conditions allow the efficient preparation of chiral tertiary thioether products $\mathbf{4 0}$ from hindered tertiary alcohols. However, the yield of the simple alkyl-substituted thioether 40e was a disappointing $17 \%$. As with other methods, the preparation of simple optically pure chiral tertiary thiols by Mitsunobutype procedures is not straightforward. Mitsunobu reactions also suffer from atom inefficiency due to the stoichiometric quantities of phosphorus-containing by-products produced by the reaction.

\subsection{Conjugate addition}

The carbon-sulfur bond of enantiomerically pure tertiary organosulfur compounds $\mathbf{4 2}$ may be constructed by facially selective addition of a sulfur nucleophile to the disubstituted terminus of a conjugated alkene 41 (Scheme 15).

$$
{ }_{41}^{\stackrel{\text { facially selective }}{\text { addition }} \longrightarrow}
$$

Scheme 15: Nucleophilic conjugate addition.

There are several examples of such facially selective addition of thiols to substituted $\mathrm{sp}^{2}$ carbon atoms, including intramolecular conjugate addition in steroidal systems $[38,39]$ and intermolecular addition directed by substrate stereochemistry [40,41] or a chiral auxiliary $[42,43]$. Despite these examples, there are very few general procedures for the preparation of chiral

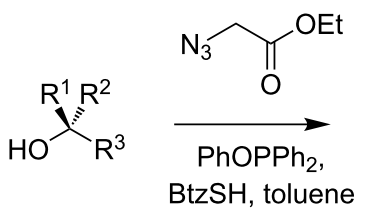

30

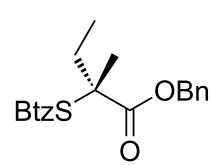

$76 \%$ $>99: 1$ er

$40 a$<smiles>CCCCCCCCS[C@@](C)(C(=O)OC)c1ccccc1</smiles>

$90 \%$

$>99: 1$ er<smiles>CCOC(=O)C(C)(C#Cc1ccccc1)CC</smiles><smiles></smiles>

$87 \%$ $96: 4$ er
$53 \%$

40d
$\mathrm{Ph}$<smiles>CCCSC(C)(C)CCP</smiles>

$17 \%$

Scheme 14: Thioethers prepared by a modified Mitsunobu reaction. 
tertiary thiols and thioethers by this method. This may be attributed to three difficulties: The low reactivity of $\beta, \beta$-disubstituted Michael receptors, the difficulty in controlling $\pi$-facial stereoselectivity, and the equilibrium of stereoisomers through an addition/elimination mechanism.

The reduced reactivity of $\beta, \beta$-disubstituted Michael receptors towards nucleophilic addition is demonstrated by the catalytic asymmetric additions of thiols to $\alpha, \beta$-unsaturated ketones [44] (R)-LaNa 3 tris(binaphthoxide) (LSB) catalyses asymmetric addition to cyclic enones (Scheme 16), and products of addition $\mathbf{4 3}$ are isolated in good yields and enantiomeric ratios.<smiles>O=C1C=CC=C1</smiles>

\section{$\mathrm{RSH}$}

$(R)$-LSB $(10 \mathrm{~mol} \%)$, toluene/THF (60:1) $-40{ }^{\circ} \mathrm{C}, 20 \mathrm{~min}$ to $41 \mathrm{~h}$

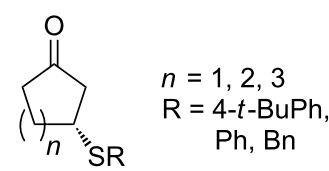

$86-94 \%$

78:22-95:5 er
Scheme 16: Asymmetric addition to cyclic enones.

However, addition to the substituted substrate $\mathbf{4 4}$ is more difficult. A higher loading of the catalyst and higher temperature are required to produce the enantioenriched thioether 45 even in moderate yield and acceptable er (Scheme 17).<smiles>CC1=CC(=O)CCC1</smiles>

44

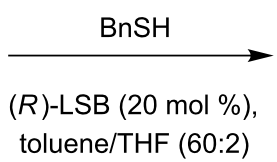

$-20^{\circ} \mathrm{C}, 43 \mathrm{~h}$

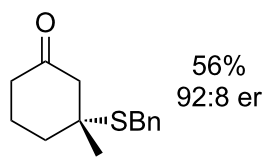

45

\section{Scheme 17: Preparation of thioether 45}

Despite the poor yield obtained with this substrate, similar conditions lead to catalytic kinetic resolution of the enantiomers of hindered enone 46 by addition, oxidation and elimination of a sulfenic acid under basic conditions (Scheme 18) [45].

Xiao and co-workers developed an organocatalytic process for the addition of thiols to nitroalkenes [46]. Using thiourea organocatalyst 48 , conjugate addition of a variety of thiols to a range of nitroalkenes 49 proceeds to give $\mathbf{5 0}$ and hence 51 in good yield and good enantioselectivity (Scheme 19).

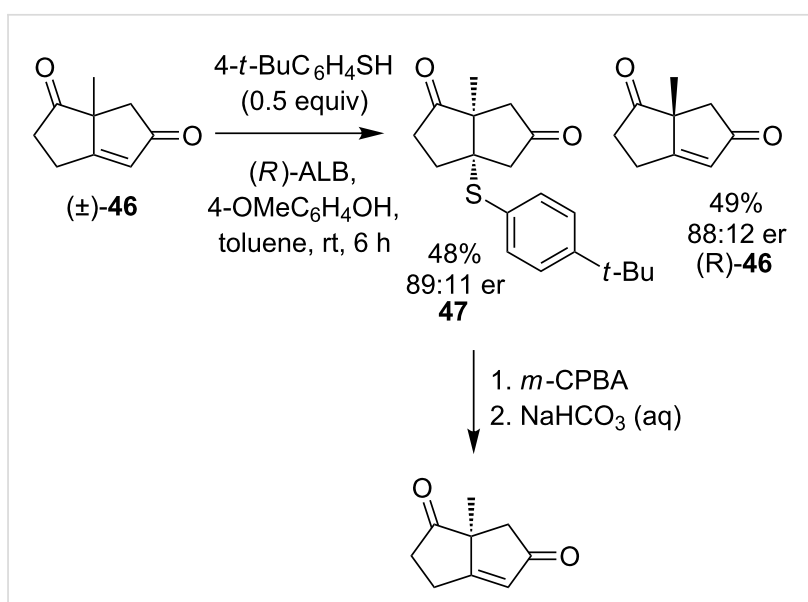

(S)-46 91\%

Scheme 18: Catalytic kinetic resolution of the enantiomers of enone 46.<smiles>C=CC1CCN2C1CCC2C(NC(=S)Nc1cc(C(F)(F)F)cc(C(F)(F)F)c1)c1ccnc2ccc(OC)cc12</smiles>

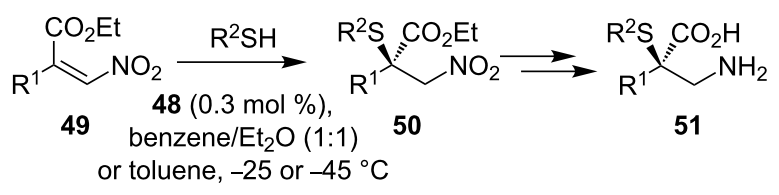

$\mathrm{R}^{1}=\mathrm{Ph}$

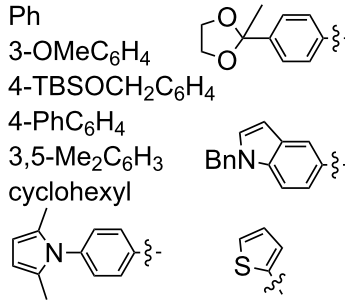

$\mathrm{R}^{2}=2-$ Naphthyl

4- $\mathrm{MeC}_{6} \mathrm{H}_{4}$

$2-\mathrm{MeC}_{6} \mathrm{H}_{4}$ $3-\mathrm{MeC}_{6} \mathrm{H}_{4}$ 4- $\mathrm{OMeC}_{6} \mathrm{H}_{4}$ 4- $t-\mathrm{BuC}_{6} \mathrm{H}_{4}$ 4- $\mathrm{FC}_{6} \mathrm{H}_{4}$ 4- $\mathrm{ClC}_{6} \mathrm{H}_{4}$ $\mathrm{Ph}$ 3,5- $-\mathrm{Me}_{2} \mathrm{C}_{6} \mathrm{H}_{3}$

Scheme 19: Organocatalytic conjugate addition to nitroalkenes 49.

$\alpha$-Arylthio- $\beta$-amino acid $\mathbf{5 4}$ was prepared from Michael adduct 52 in three steps (Scheme 20) in good yield and with full conservation of enantiomeric purity.

Palomo and co-workers postulated that poor reactivity and facial selectivity in conjugate additions with sulfur could be minimised by an intramolecular approach $[47,48]$. A Lewis acid-promoted sulfur migration within $\mathrm{N}$-enoyl oxazolidine-2thione substrates $\mathbf{5 6}$ followed by hydrolysis gave optically pure 


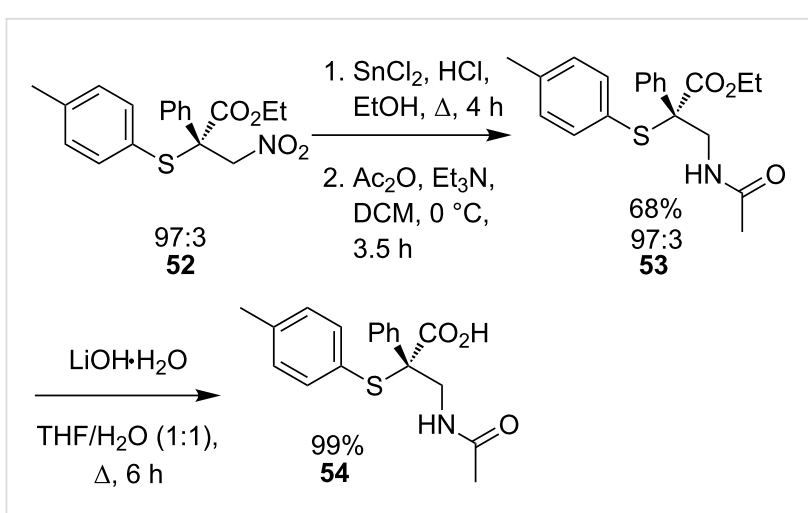

Scheme 20: Preparation of $\beta$-amino acid 54.
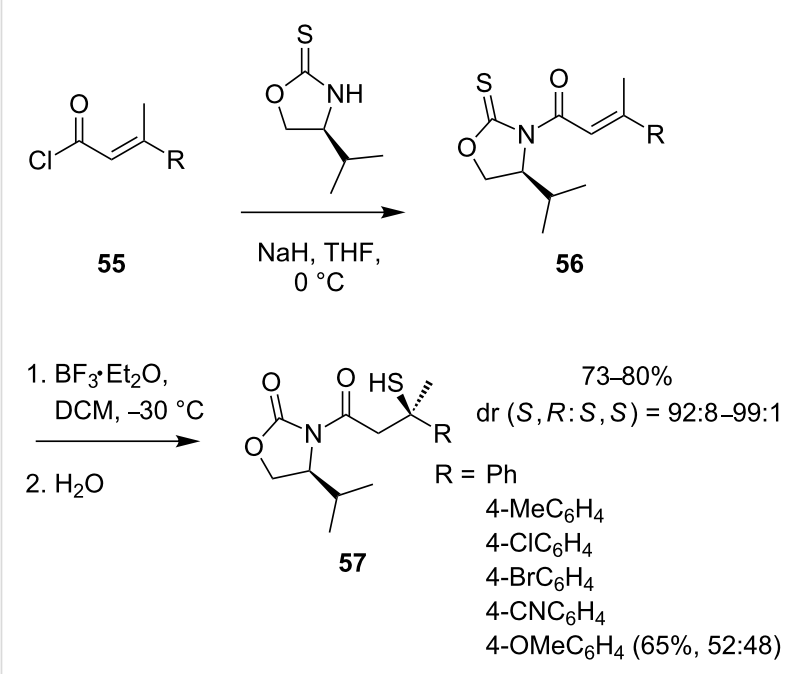

Scheme 21: Sulfur migration within oxazolidine-2-thiones 56.

tertiary thiols 57 directly (Scheme 21), with only the electron rich para-methoxyphenyl substituent performing poorly.

As with stereospecific nucleophilic displacement, only specific substrates are tolerated in conjugate additions, and further functionality is always required to activate the electrophilic alkene towards attack by the sulfur nucleophile.

\section{Carbon-carbon bond formation}

\subsection{Electrophilic addition to $\alpha$-thioenolates}

Diastereoselective alkylation of $\alpha$-thioenolates has been used to prepare several types of enantiomerically pure tertiary thioethers [49-54]. The method of "self-regeneration of stereocentres" developed by Seebach [55] employs $\alpha$-thiocarboxylic acids 58 condensed with pivaldehyde to generate 1,3-oxathiolan-4-ones 59 (Scheme 22) [49,50]. The cis diastereomer is formed preferentially (2:1-8:1 selectivity), and can usually be purified by crystallisation. Enolate $\mathbf{6 0}$ is formed by deprotonation with a lithium base and treated with an electrophile. Elec- trophilic addition takes place diastereoselectively anti to the bulky tert-butyl group, producing oxathiolanone products $\mathbf{6 1}$ in excellent diastereoselectivities.

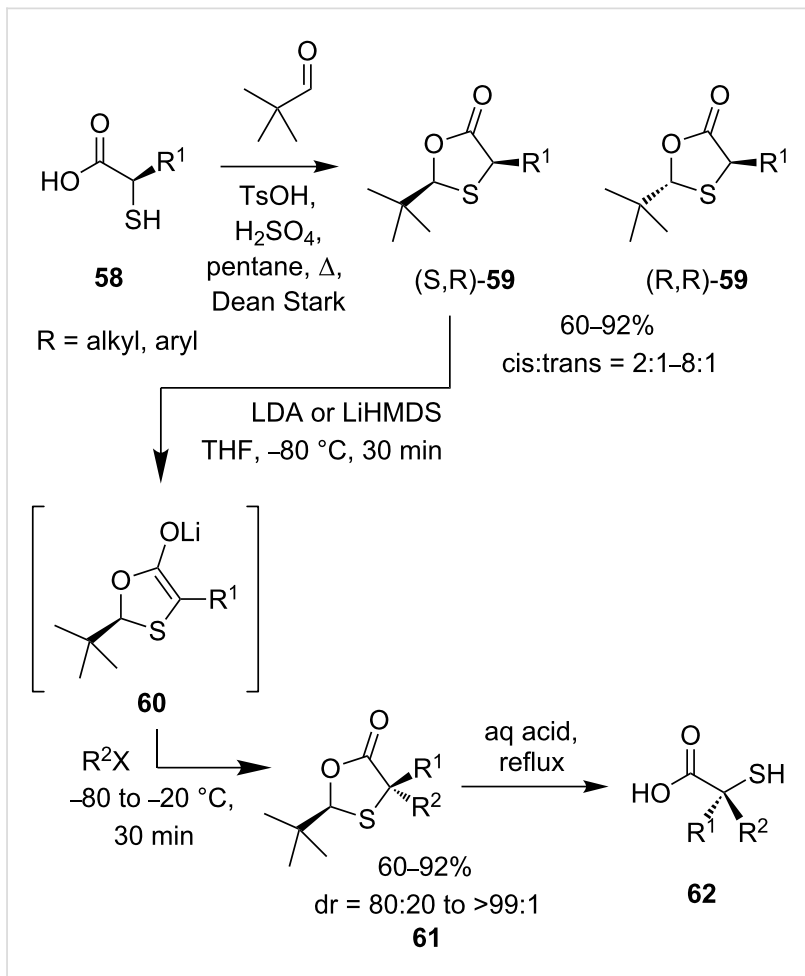

Scheme 22: Preparation of thiols $\mathbf{6 2}$ by self-regeneration of stereocentres.

Enantiopure tertiary thiols $\mathbf{6 2}$ can be liberated from the oxathiolanone products by hydrolysis, and the method was employed by Townsend and co-workers in the synthesis of $(5 R)$-thiolactomycin (66, Scheme 23) [51]. Diastereoselective addition of an aldehyde to oxathiolanone $\mathbf{6 4}$ affords $\mathbf{6 5}$ in $81 \%$ yield. Further synthetic manipulations allowed preparation of $(5 R)$-thiolactomycin (66) in $>99: 1$ er.

\subsection{Electrophilic attack on $\alpha$-thioorganolithiums}

Formation of carbon-carbon bonds adjacent to heteroatoms by deprotonation with an organolithium base and subsequent reaction with an electrophile has become an important and versatile method, especially when chiral ligands may be used to govern the enantioselectivity of the reaction pathway [56]. Tertiary organosulfur compounds can be made in this way by lithiation of a chiral secondary thiol derivative (Scheme 24).

Three conditions must be met if this method is to be used for preparation of enantiomerically pure tertiary thiol derivatives:

1) The substrate $\mathbf{6 7}$ must be available in an enantiomerically pure form, 


$$
\text { HO }
$$

63

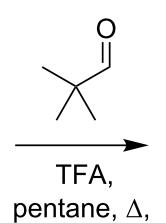

Dean Stark

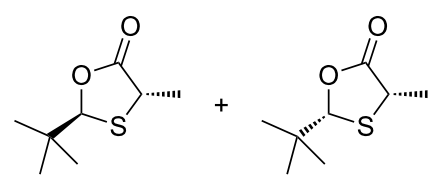

(S,S)-64 $\quad 99 \% \quad(R, S)-64$ trans:cis $=1: 2.5$

$$
\text { 1. LDA, THF }
$$

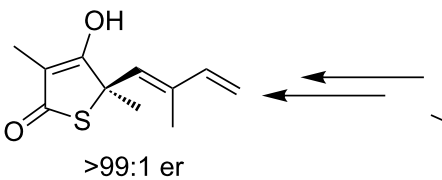

$>99: 1$ er

$(5 R)$-thiolactomycin

66

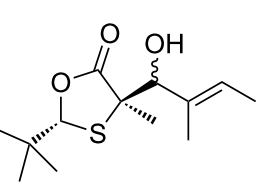

$81 \%$
65
Scheme 23: Synthesis of $(5 R)$-thiolactomycin.

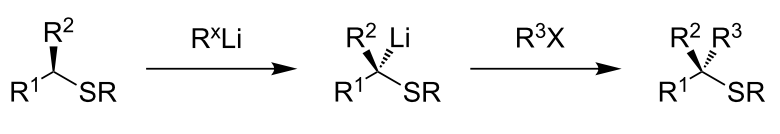

67

68
Scheme 24: Preparation of tertiary thiols and thioethers via a-thioorganolithiums.

2) The lithiated intermediate $\mathbf{6 8}$ must be configurationally stable, and

3) Electrophilic addition to give $\mathbf{6 9}$ must proceed with either complete retention or complete inversion of stereochemistry.

\subsubsection{Configurational stability in $\alpha$-thioorganolithiums}

In contrast to $\alpha$-oxy and $\alpha$-aminoorganolithiums, simple $\alpha$-thioorganolithium compounds show high configurational lability even at $-80^{\circ} \mathrm{C}$ [57]. Beak noted configurational instability during the diastereoselective methylation of $\alpha$-thioorganolithium 71 (Scheme 25) [58]. Equilibration of the diastereoisomers of $\mathbf{7 1}$ favoured axial methylation of the lithiated intermediate to give $\mathbf{7 2}$.

Studies by both Hoffmann and co-workers $[59,60]$ and by Reich and co-workers [61] showed that the rate determining step for racemisation of $\alpha$-thio, $\alpha$-seleno and $\alpha$-telluroorganolithiums is rotation about the $\mathrm{C}-\mathrm{S}$, Se or Te bond [62]. Simple inversion in $\alpha$-thio-substituted carbanions has a barrier as low as 0.5

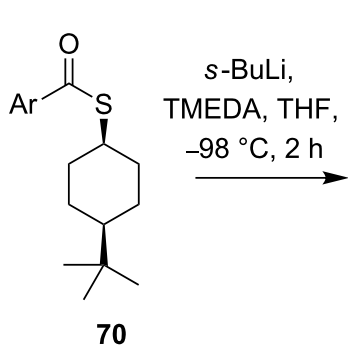<smiles>CC#CCCC(Cl)(SC(=O)Br)SC(Cl)(CCC(CCC(C)(C)C)C(C)(C)C)CCC(C)(C)C</smiles>

71<smiles>CC(C)(C)[C@H]1CC[C@](C)(SC(=O)[AlH2])CC1</smiles>

Scheme 25: Diastereoselective methylation of organolithium 71

$\mathrm{kcal} \cdot \mathrm{mol}^{-1}$ [63] making inversion itself unlikely to comprise the rate determining step of the racemisation. Consistent with this explanation, the barrier to racemisation increases with greater steric bulk in the chalcogen substituent.

\subsubsection{Lithiation and alkylation of thiocarbamates}

Hoppe and co-workers applied the observations of Hoffmann and Reich in comprehensive studies on configurationally stable $\alpha$-lithiothiocarbamates. Stereoselective deprotonations of thiocarbamate 73 in the presence of (-)-sparteine 74 (Scheme 26) were attempted [64].

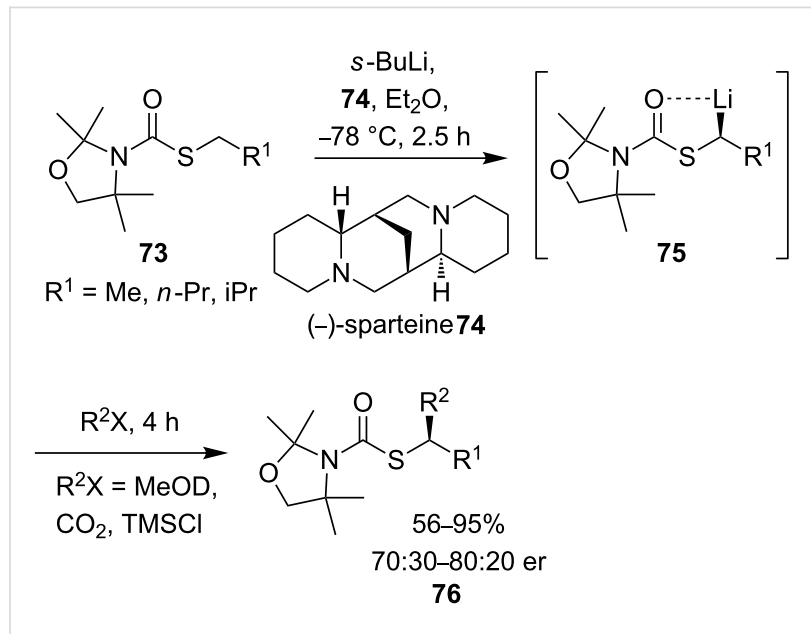

Scheme 26: Addition to lithiated thiocarbamate $\mathbf{7 5 .}$

Trapping the lithiated intermediate $\mathbf{7 5}$ with electrophiles gave products with poor enantioselectivities, but the results gave no 
indication of the configurational stability of the intermediate organolithium 75. To establish the factors governing enantioselectivity in the electrophilic substitution of 73, Hoppe made use of an extremely high kinetic H/D isotope effect observed for deprotonation in similar compounds [65]. Reaction of a test substrate demonstrated an isotope effect of $k_{\mathrm{H}} / k_{\mathrm{D}} \geq 100$. A racemic mixture of 77 was lithiated in the presence of (-)-sparteine and quenched with trimethylsilyl chloride (Scheme 27). Deuterated thiocarbamate 78 containing $>99 \%$ deuterium was isolated from the reaction with an enantiomeric ratio of $67: 33$. The high deuterium content of the product indicated that both enantiomers of $\mathbf{7 7}$ must have been deprotonated, and thus that the lithio derivative of thiocarbamate 77 must be configurationally labile since the product is non-racemic.

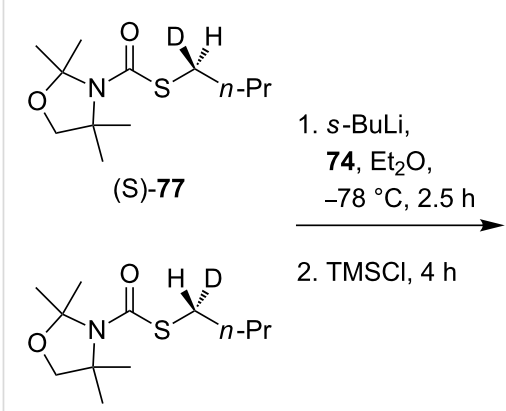

(R)-77

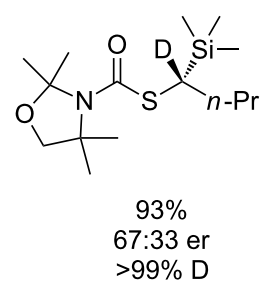

78
Scheme 27: Configurational lability in unhindered a-lithiothiocarbamates.

In order to induce greater configurational stability, thiocarbamate 79, with increased steric bulk, was prepared. A sample of 79 with an enantiomeric ratio of 73:27 was lithiated with secbutyllithium in diethyl ether and TMEDA at $-78{ }^{\circ} \mathrm{C}$ for 2.5 hours and quenched with $\mathrm{MeOD}$ (Scheme 28). Deuterated thiocarbamate 78 was isolated with an enantiomeric ratio of 72:28, indicating almost full conservation of enantiomeric purity and

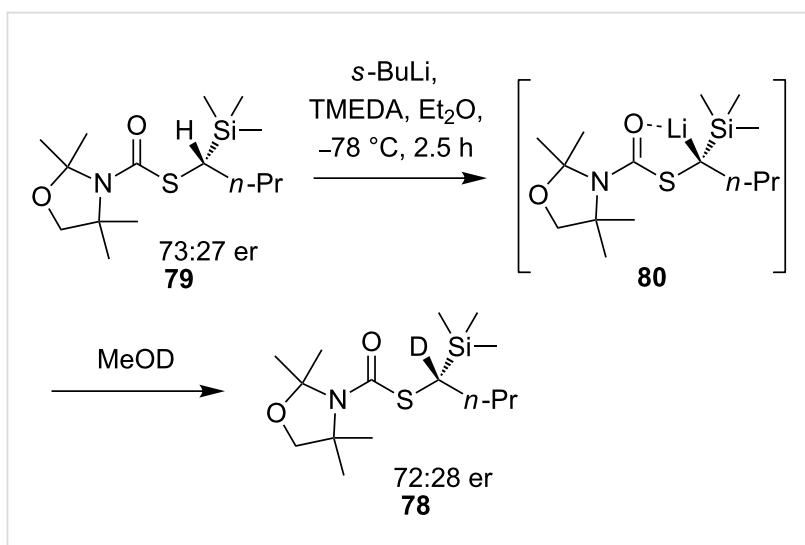

Scheme 28: Configurational stability in bulky a-lithiothiocarbamates. hence demonstrating that the more congested organolithium $\mathbf{8 0}$ is now configurationally stable under the reaction conditions. Enantiomerically pure tertiary thiols can be liberated from the substitution products by cleavage of the carbamoyl functionality, providing a rare asymmetric route to simple unfunctionalised tertiary thiols.

The lithio derivative of benzylic thiocarbamate $\mathbf{8 1}$ was also configurationally stable in diethyl ether and TMEDA at $-78{ }^{\circ} \mathrm{C}$ $[66,67]$. Reaction with a series of electrophiles allowed isolation of functionalised thiocarbamates $\mathbf{8 3}$ in excellent yield and enantiomeric ratio (Scheme 29). Benzylic organolithiums are notorious for the lack of consistency with which they undergo electrophilic substitution [56], and $\mathbf{8 2}$ is remarkable in that all electrophiles, except protonating agents, react with complete inversion of configuration.
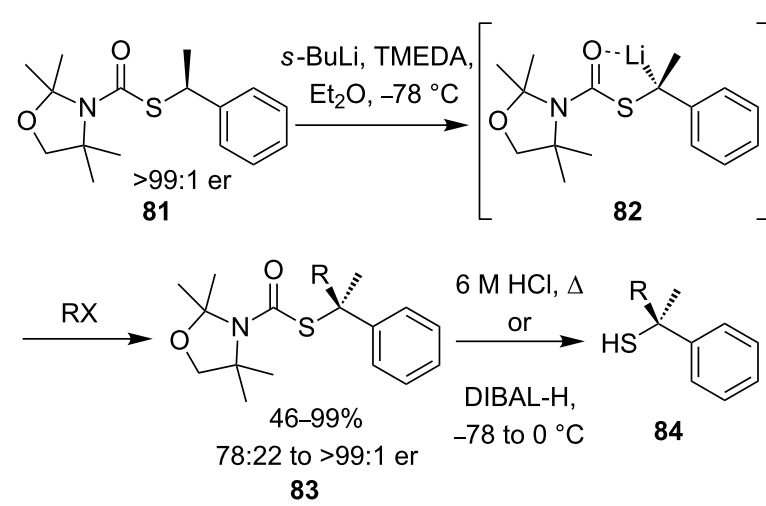

$\mathrm{RX}=$ acid chlorides, anhydrides, aldehydes, ketones, alkyl halides, allyl bromide, benzyl bromide, TMSCI

Scheme 29: Asymmetric functionalisation of secondary benzylic thiocarbamates.

Enantiopure cyclohexenyl thiocarbamates also form configurationally stable $\alpha$-thioallyllithium species [68-70]. Lithiation of thiocarbamate $\mathbf{8 5}$ followed by methylation results in the isolation of regioisomeric products arising from electrophilic substitution at either end of the lithioallyl system (Scheme 30).

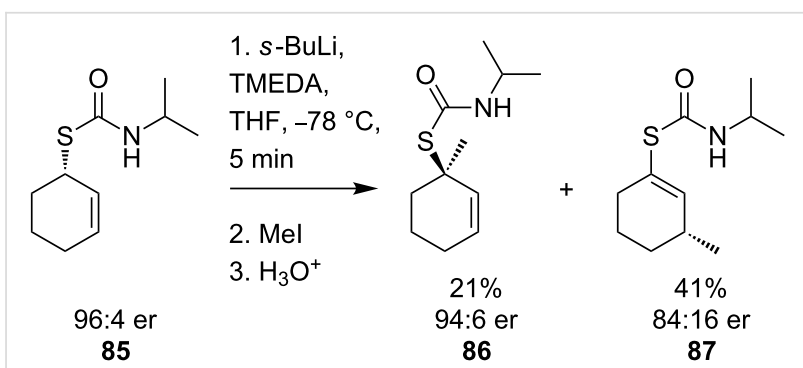

Scheme 30: Methylation of lithioallyl thiocarbamates. 
<smiles>CC(C)N(C(=O)SC1C=CCCC1)C(C)C</smiles>

$98: 2$ er 88
1. $s$-BuLi, TMEDA $-78^{\circ} \mathrm{C}$, solvent, $30-125 \mathrm{~min}$

2. $\mathrm{RX},-78$ to $0^{\circ} \mathrm{C}$

$\mathrm{RX}=\mathrm{Mel}$

$n$-Hexyl-I

$\mathrm{BnBr}$

$\mathrm{NBr}^{\mathrm{Br}}$

$\mathrm{Ph} \leadsto \mathrm{Br}$<smiles>[R]C1(SC(=O)N(C(C)C)C(C)C)C=CCCC1</smiles>

$67-99 \%$

97:3-98:2 er

89

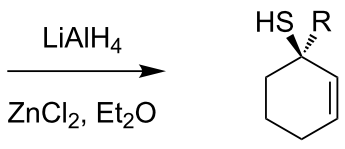

$59-90 \%$

97:3-98:2 er

90

Scheme 31: Asymmetric preparation of tertiary allylic thiols.

In the case of the secondary thiocarbamate, the $\gamma$-substituted product 87 is preferentially formed, whilst with an $\mathrm{N}, \mathrm{N}$-diisopropylthiocarbamate selective formation of the $\alpha$-substituted product $\mathbf{8 9}$ (Scheme 31) is observed.

Reduction of the functionalised thiocarbamate products $\mathbf{8 9}$ with lithium aluminium hydride affords enantiomerically pure thiols 90 in excellent yields and enantiomeric ratios.

\subsubsection{Lithiation and rearrangement of thiocarba- mates}

Carbon-carbon bond formation in configurationally stable $\alpha$-thioorganolithiums allows access to non-racemic tertiary thiols of varying structure and complexity. Hoppe's extensive studies of lithiated thiocarbamates have continued to display the synthetic utility of these species in the formation of secondary thiol derivatives. These were prepared by diastereoselective electrophilic additions in proline-derived systems [71,72] and asymmetric alkylation of thiocarbamates in the presence of a chiral ligand $[73,74]$. Stereospecific functionalisation of configurationally stable lithiated thiocarbamates with electrophiles is general for a range of structures, but until very recently it has not been applicable to arylation reactions. However, we have discovered [75] a variant of a rearrangement reaction of lithiated ureas that we first reported in 2007 [76] in which a lithiated thiocarbamate undergoes an intramolecular aryl transfer. Treatment of an $\mathrm{N}$-aryl $\mathrm{S}$-benzyl thiocarbamate $\mathbf{9 2}$ leads to formation of a lithio derivative $\mathbf{9 3}$ comparable with those reported by Hoppe (Scheme 32). As in the case of lithiated $N$-aryl ureas [76-80] and $N$-aryl carbamates [81,82], the $N$-aryl ring is susceptible to attack by the anionic centre, and migration of the ring to the position $\alpha$ to sulfur occurs, presumably via an intermediate related to $\mathbf{9 4}$. After work up the product is a tertiary thiocarbamate $\mathbf{9 5}$, and simple mildly basic hydrolysis leads to the tertiary thiol 96. The aryl migration is applicable to a range of products 96 (Table 1) and amounts to an intramolecular arylation, allowing the formation of otherwise inaccessible doubly benzylic tertiary thiols in enantiomerically enriched form from benzylic alcohols 91. Similar to the rearrangement of lithiated ureas [76] (but interestingly in contrast to the rearrangement of lithiated carbamates $[81,82]$ ), aryl migration proceeds with retention of stereochemistry. Current work is continuing with the aim of expanding the utility of this new mode of reactivity displayed by thiocarbamates.
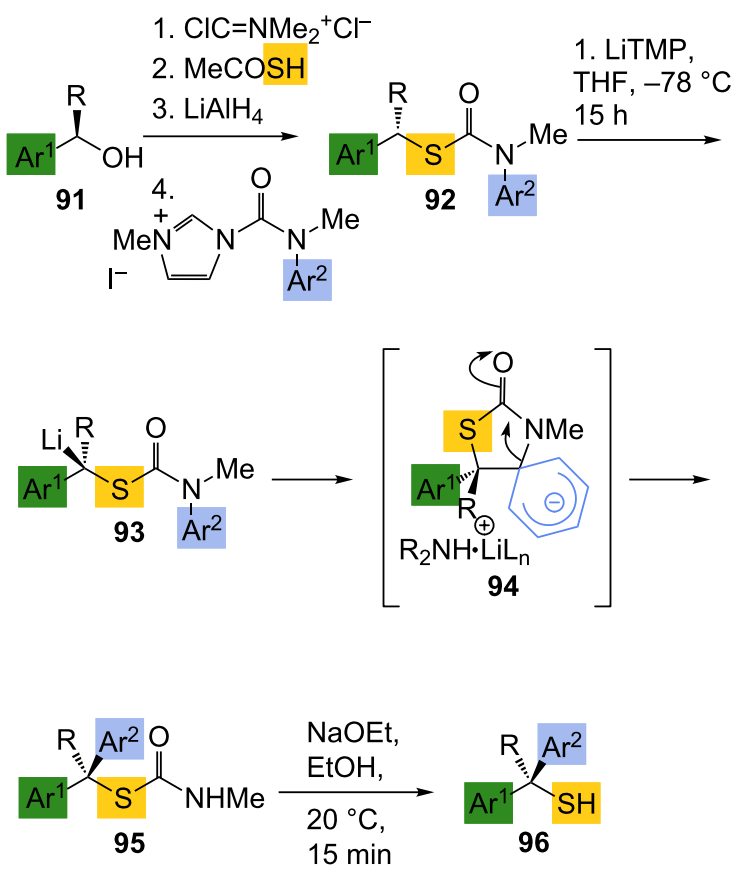

Scheme 32: Asymmetric preparation of thiols 96 by aryl migration in lithiated thiocarbamates. 


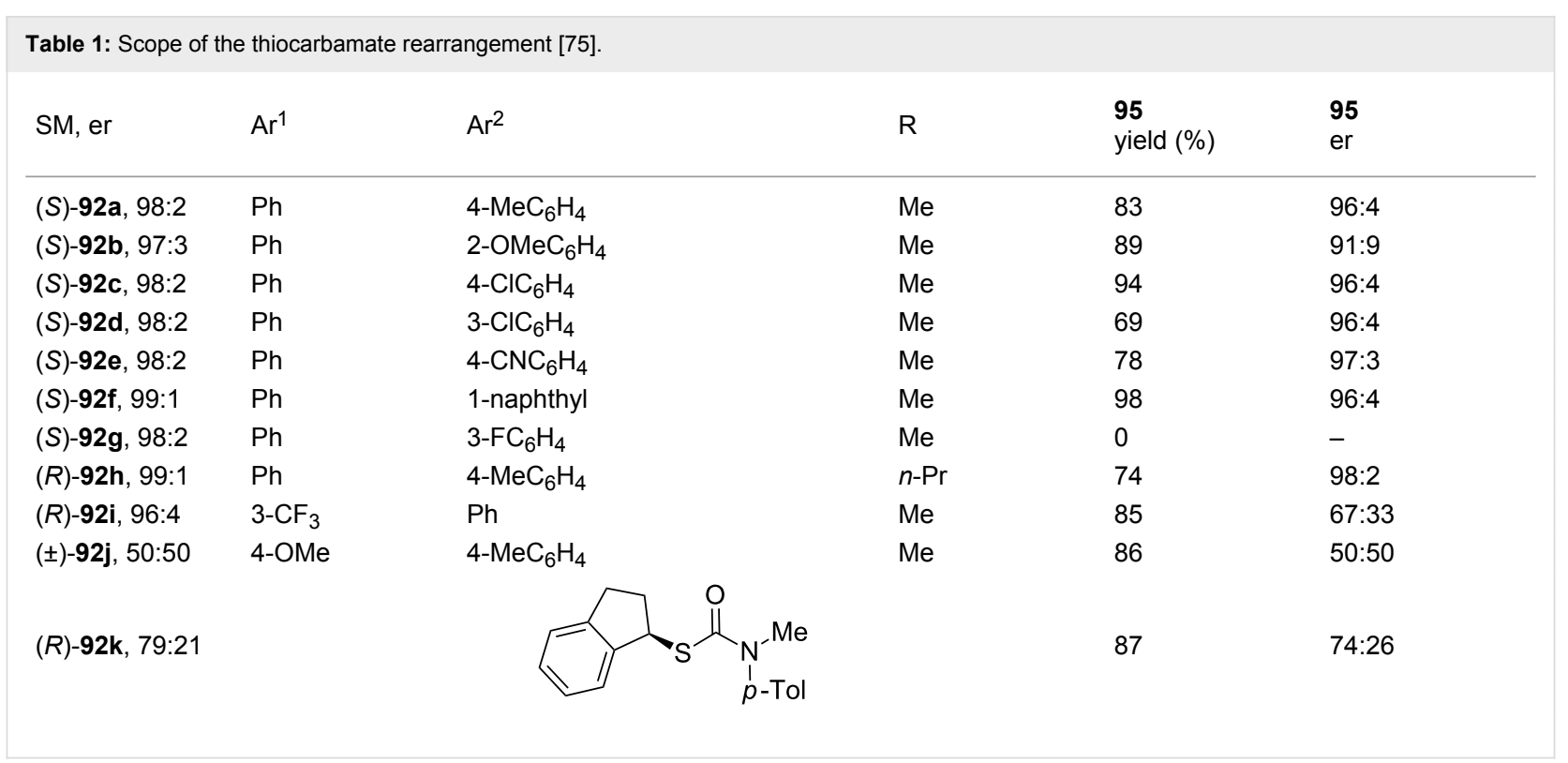

\section{Conclusion}

Of the methods available for the synthesis of tertiary thiols, the majority (for example, those involving epoxide opening or electrophilic attack on thio-substituted enolates) lead to thiols carrying further functionality in some form. Tertiary thiols without further functionality are still challenging, with organolithium-based alkylations and arylation (by rearrangement) of thiocarbamates offering the best prospects. Further developments in this area - particularly with regard to carbolithiation reactions [79] - are to be expected.

\section{Acknowledgements}

We are grateful to the Royal Society of Chemistry for a Briggs Scholarship (to PM) and for the Hickinbottom Fellowship (to $\mathrm{JC})$.

\section{References}

1. 2009 Top 200 Branded Drugs by Retail Dollars. Drug Topics, 2010; http://drugtopics.modernmedicine.com/drugtopics/data/articlestandard// drugtopics/252010/674961/article.pdf.

2. Cremlyn, R. J. An Introduction to Organosulfur Chemistry; John Wiley \& Sons Ltd.: Chichester, U.K., 1996.

3. Toru, T.; Bolm, C., Eds. Organosulfur Chemistry in Asymmetric Synthesis; Wiley-VCH: Weinheim, Germany, 2008.

4. Fernández, I.; Khiar, N. Chem. Rev. 2003, 103, 3651-3706. doi:10.1021/cr990372u

5. Pellissier, H. Tetrahedron 2006, 62, 5559-5601. doi:10.1016/j.tet.2006.03.093

6. Mellah, M.; Voituriez, A.; Schulz, E. Chem. Rev. 2007, 107, 5133-5205. doi:10.1021/cr068440h

7. Carreño, M. C.; Hernández-Torres, G.; Ribagorda, M.; Urbano, A. Chem. Commun. 2009, 6129-6144. doi:10.1039/B908043K

8. Wojaczyńska, E.; Wojaczyński, J. Chem. Rev. 2010, 110, 4303-4356. doi:10.1021/cr900147h
9. Procter, D. J. J. Chem. Soc., Perkin Trans. 1 2001, 335-354. doi:10.1039/b002081h

10. Shibasaki, M.; Kanai, M. Chem. Rev. 2008, 108, 2853-2873. doi:10.1021/cr078340r

11. Voss, J. J. Sulfur Chem. 2009, 30, 167-207. doi:10.1080/17415990802673017

12. Weaver, J. D.; Morris, D. K.; Tunge, J. A. Synlett 2010, 470-474. doi:10.1055/s-0029-1219186

13. Effenberger, F.; Gaupp, S. Tetrahedron: Asymmetry 1999, 10 , 1765-1775. doi:10.1016/S0957-4166(99)00154-8

14. Monde, K.; Taniguchi, T.; Miura, N.; Nishimura, S.-I.; Harada, N.; Dukor, R. K.; Nafie, L. A. Tetrahedron Lett. 2003, 44, 6017-6020. doi:10.1016/S0040-4039(03)01513-2

15. Avenoza, A.; Busto, J. H.; Corzana, F.; Jiménez-Osés, G.; Peregrina, J. M. Chem. Commun. 2004, 980-981. doi:10.1039/b400282b

16. Avenoza, A.; Busto, J. H.; Jiménez-Osés, G.; Peregrina, J. M. J. Org. Chem. 2006, 71, 1692-1695. doi:10.1021/jo051632c

17. Avenoza, A.; Busto, J. H.; Jiménez-Osés, G.; Peregrina, J. M. Org. Lett. 2006, 8, 2855-2858. doi:10.1021/ol060993r

18. Bednarski, P. J.; Nelson, S. D. J. Med. Chem. 1989, 32, 203-213. doi:10.1021/jm00121a037

19. Kitagawa, I.; Ueda, Y.; Kawasaki, T.; Mosettig, E. J. Org. Chem. 1963, 28, 2228-2232. doi:10.1021/jo01044a018

20. Komeno, T.; Kishi, M. Tetrahedron 1971, 27, 1517-1526. doi:10.1016/S0040-4020(01)98017-2

21. Caine, D.; Crews, E.; Salvino, J. M. Tetrahedron Lett. 1983, 24 , 2083-2086. doi:10.1016/S0040-4039(00)81850-X

22. Tatsuta, K.; Suzuki, Y.; Toriumi, T.; Furuya, Y.; Hosokawa, S. Tetrahedron Lett. 2007, 48, 8018-8021. doi:10.1016/j.tetlet.2007.09.039

23. López, I.; Rodríguez, S.; Izquierdo, J.; González, F. V. J. Org. Chem. 2007, 72, 6614-6617. doi:10.1021/jo0709955

24. Mitsunobu, O. Synthesis 1981, 1-28. doi:10.1055/s-1981-29317

25. Kumara Swamy, K. C.; Bhuvan Kumar, N. N.; Balaraman, E.; Pavan Kumar, K. V. P. Chem. Rev. 2009, 109, 2551-2651. doi:10.1021/cr800278z 
26. Walker, K. A. M. Tetrahedron Lett. 1977, 18, 4475-4478. doi:10.1016/S0040-4039(01)83541-3

27. Kotsuki, H.; Matsumoto, K.; Nishizawa, H. Tetrahedron Lett. 1991, 32, 4155-4158. doi:10.1016/S0040-4039(00)79890-X

28. Shi, Y.-J.; Hughes, D. L.; McNamara, J. M. Tetrahedron Lett. 2003, 44, 3609-3611. doi:10.1016/S0040-4039(03)00728-7

29. La Clair, J. J. Angew. Chem., Int. Ed. 2006, 45, 2769-2773. doi:10.1002/anie.200504033

30. Marris, E. Nature 2006, 442, 492-493. doi:10.1038/442492c

31. Rychnovsky, S. D. Org. Lett. 2006, 8, 2895-2898. doi:10.1021/ol0611346

32. Porco, J. A., Jr.; Su, S.; Lei, X.; Bardhan, S.; Rychnovsky, S. D. Angew. Chem., Int. Ed. 2006, 45, 5790-5792. doi:10.1002/anie.200602854

33. Ikegai, K.; Pluempanupat, W.; Mukaiyama, T. Chem. Lett. 2005, 34, 638-639. doi:10.1246/cl.2005.638

34. Ikegai, K.; Pluempanupat, W.; Mukaiyama, T. Bull. Chem. Soc. Jpn. 2006, 79, 780-790. doi:10.1246/bcsj.79.780

35. Kuroda, K.; Maruyama, Y.; Hayashi, Y.; Mukaiyama, T. Chem. Lett. 2008, 37, 836-837. doi:10.1246/cl.2008.836

36. Kuroda, K.; Maruyama, Y.; Hayashi, Y.; Mukaiyama, T. Bull. Chem. Soc. Jpn. 2009, 82, 381-392. doi:10.1246/bcsj.82.381

37. Mukaiyama, T.; Kuroda, K.; Maruyama, Y. Heterocycles 2010, 80, 63-82. doi:10.3987/REV-09-SR(S)1

38. Childers, W. E.; Furth, P. S.; Shih, M.-J.; Robinson, C. H. J. Org. Chem. 1988, 53, 5947-5951. doi:10.1021/jo00260a026

39. Lesuisse, D.; Gourvest, J.-F.; Benslimane, O.; Canu, F.; Delaisi, C.; Doucet, B.; Hartmann, C.; Lefrançois, J.-M.; Tric, B.; Mansuy, D.; Philibert, D.; Teutsch, G. J. Med. Chem. 1996, 39, 757-772. doi:10.1021/jm950539l

40. Hanessian, S.; Reddy, B. Tetrahedron 1999, 55, 3427-3443. doi:10.1016/S0040-4020(98)01152-1

41. McDevitt, J. P.; Lansbury, P. T., Jr. J. Am. Chem. Soc. 1996, 118, 3818-3828. doi:10.1021/ja9525622

42. Ohata, K.; Terashima, S. Tetrahedron Lett. 2006, 47, 2787-2791. doi:10.1016/j.tetlet.2006.02.058

43. Ohata, K.; Terashima, S. Bioorg. Med. Chem. Lett. 2007, 17, 4070-4074. doi:10.1016/j.bmcl.2007.04.067

44. Emori, E.; Arai, T.; Sasai, H.; Shibasaki, M. J. Am. Chem. Soc. 1998, 120, 4043-4044. doi:10.1021/ja980397v

45. Emori, E.; lida, T.; Shibasaki, M. J. Org. Chem. 1999, 64, 5318-5320. doi:10.1021/jo9904922

46. Lu, H.-H.; Zhang, F.-G.; Meng, X.-G.; Duan, S.-W.; Xiao, W.-J. Org. Lett. 2009, 11, 3946-3949. doi:10.1021/ol901572x

47. Palomo, C.; Oiarbide, M.; Dias, F.; López, R.; Linden, A. Angew. Chem., Int. Ed. 2004, 43, 3307-3310. doi:10.1002/anie.200453889

48. Palomo, C.; Oiarbide, M.; López, R.; González, P. B.; Gómez-Bengoa, E.; Saá, J. M.; Linden, A. J. Am. Chem. Soc. 2006, 128, 15236-15247. doi:10.1021/ja0654027

49. Strijtveen, B.; Kellogg, R. M. J. Org. Chem. 1986, 51, 3664-3671. doi:10.1021/jo00369a020

50. Strijtveen, B.; Kellogg, R. M. Tetrahedron 1987, 43, 5039-5054. doi:10.1016/S0040-4020(01)87682-1

51. McFadden, J. M.; Frehywot, G. L.; Townsend, C. A. Org. Lett. 2002, 4, 3859-3862. doi:10.1021/ol026685k

52. Alibés, R.; Bayón, P.; de March, P.; Figueredo, M.; Font, J.; Marjanet, G. Org. Lett. 2006, 8, 1617-1620. doi:10.1021/ol060173e

53. Arpin, A.; Manthorpe, J. M.; Gleason, J. L. Org. Lett. 2006, 8, 1359-1362. doi:10.1021/ol060106k
54. Tiong, E. A.; Gleason, J. L. Org. Lett. 2009, 11, 1725-1728. doi:10.1021/ol802643k

55. Seebach, D.; Naef, R.; Calderari, G. Tetrahedron 1984, 40, 1313-1324. doi:10.1016/S0040-4020(01)82417-0

56. Clayden, J. Organolithiums: Selectivity for Synthesis; Tetrahedron Organic Chemistry Series, Vol. 23; Pergamon: Oxford, U.K., 2002.

57. McDougal, P. G.; Condon, B. D.; Laffosse, M. D., Jr.; Lauro, A. M.; VanDerveer, D. Tetrahedron Lett. 1988, 29, 2547-2550. doi:10.1016/S0040-4039(00)86108-0

58. Beak, P.; Becker, P. D. J. Org. Chem. 1982, 47, 3855-3861. doi:10.1021/jo00141a010

59. Ruhland, T.; Dress, R. K.; Hoffmann, R. W. Angew. Chem., Int. Ed. Engl. 1993, 32, 1467-1468. doi:10.1002/anie.199314671

60. Hoffmann, R. W.; Dress, R. K.; Ruhland, T.; Wenzel, A. Chem. Ber. 1995, 128, 861-870. doi:10.1002/cber.19951280903

61. Reich, H. J.; Dykstra, R. R. Angew. Chem., Int. Ed. Engl. 1993, 32, 1469-1470. doi:10.1002/anie.199314691

62. Aggarwal, V. K. Angew. Chem., Int. Ed. Engl. 1994, 33, 175-177. doi:10.1002/anie.199401751

63. Wiberg, K. B.; Castejon, H. J. Am. Chem. Soc. 1994, 116, 10489-10497. doi:10.1021/ja00102a016

64. Kaiser, B.; Hoppe, D. Angew. Chem., Int. Ed. Engl. 1995, 34, 323-325. doi:10.1002/anie.199503231

65. Hoppe, D.; Paetow, M.; Hintze, F. Angew. Chem., Int. Ed. Engl. 1993, 32, 394-396. doi:10.1002/anie.199303941

66. Hoppe, D.; Kaiser, B.; Stratmann, O.; Fröhlich, R. Angew. Chem., Int. Ed. Engl. 1997, 36, 2784-2786. doi:10.1002/anie.199727841

67. Stratmann, O.; Kaiser, B.; Fröhlich, R.; Meyer, O.; Hoppe, D. Chem.-Eur. J. 2001, 7, 423-435. doi:10.1002/1521-3765(20010119)7:2<423::AID-CHEM423>3.0.CO;2$Y$

68. Marr, F.; Fröhlich, R.; Hoppe, D. Org. Lett. 1999, 1, $2081-2083$. doi:10.1021/ol991134o

69. Marr, F.; Hoppe, D. Org. Lett. 2002, 4, 4217-4220. doi:10.1021/ol0266828

70. Marr, F.; Fröhlich, R.; Wibbeling, B.; Diedrich, C.; Hoppe, D. Eur. J. Org. Chem. 2002, 2970-2988. doi:10.1002/1099-0690(200209)2002:17<2970::AID-EJOC2970>3.0.C O;2-J

71. Sonawane, R. P.; Fröhlich, R.; Hoppe, D. Chem. Commun. 2006, 3101-3103. doi:10.1039/b604029b

72. Sonawane, R. P.; Mück-Lichtenfeld, C.; Fröhlich, R.; Bergander, K.; Hoppe, D. Chem.-Eur. J. 2007, 13, 6419-6429. doi:10.1002/chem.200601853

73. Sonawane, R. P.; Fröhlich, R.; Hoppe, D. Adv. Synth. Catal. 2006, 348, 1847-1854. doi:10.1002/adsc.200606177

74. Lange, H.; Bergander, K.; Frölich, R.; Kehr, S.; Nakamura, S.; Shibata, N.; Toru, T.; Hoppe, D. Chem.-Asian J. 2008, 3, 88-101. doi:10.1002/asia.200700262

75. MacLellan, P.; Clayden, J. Chem. Commun. 2011, 47, 3395-3397. doi:10.1039/C0CC04912C

76. Clayden, J.; Dufour, J.; Grainger, D. M.; Helliwell, M. J. Am. Chem. Soc. 2007, 129, 7488-7489. doi:10.1021/ja071523a

77. Clayden, J.; Hennecke, U. Org. Lett. 2008, 10, 3567-3570. doi:10.1021/ol801332n

78. Bach, R.; Clayden, J.; Hennecke, U. Synlett 2009, 421-424. doi:10.1055/s-0028-1087543 
79. Clayden, J.; Donnard, M.; Lefranc, J.; Minassi, A.; Tetlow, D. J.

J. Am. Chem. Soc. 2010, 132, 6624-6625. doi:10.1021/ja1007992

80. Tetlow, D. J.; Hennecke, U.; Raftery, J.; Waring, M. J.; Clarke, D. S.; Clayden, J. Org. Lett. 2010, 12, 5442-5445. doi:10.1021/ol102155h

81. Clayden, J.; Farnaby, W.; Grainger, D. M.; Hennecke, U.;

Mancinelli, M.; Tetlow, D. J.; Hillier, I. H.; Vincent, M. A.

J. Am. Chem. Soc. 2009, 131, 3410-3411. doi:10.1021/ja808959e

82. Fournier, A. M.; Brown, R. A.; Farnaby, W.; Miyatake-Ondozabal, H.; Clayden, J. Org. Lett. 2010, 12, 2222-2225. doi:10.1021/ol100627c

\section{License and Terms}

This is an Open Access article under the terms of the Creative Commons Attribution License

(http://creativecommons.org/licenses/by/2.0), which permits unrestricted use, distribution, and reproduction in any medium, provided the original work is properly cited.

The license is subject to the Beilstein Journal of Organic Chemistry terms and conditions:

(http://www.beilstein-journals.org/bjoc)

The definitive version of this article is the electronic one which can be found at: doi:10.3762/bjoc. 7.68 